\title{
Effect of Kapalbhati on Blood Pressure in Naive
}

\author{
Santosh Kumar Jha1, Rajesh Kumar Goit², Kshitiz Upadhyay-Dhungel ${ }^{3}$
}

\author{
Department of Physiology \\ Nepalgunj Medical College Teaching Hospital, Nepalgunj, Nepal
}

${ }^{1}$ Lecturer, Nepalgunj Medical College Teaching Hospital, Nepal

${ }^{2}$ Assistant Professor, Nepalgunj Medical College Teaching Hospital, Nepal

${ }^{3}$ Professor, Human Physiology, CAFODAT, KTM, Nepal

\section{ABSTRACT}

Background and Objectives: Kapalbhati is among one of the cleansing act (shatkarma) in yogic philosophy. It is highly recommended for those who have to do great deal of study and need a clean, clear mind. This study was conducted among medical students at Nepalgunj medical college, Nepalgunj, Nepal.

Material and Methods: This analytical study was conducted among 100 medical students of Nepalgunj Medical College, Nepalgunj, Nepal who gave consent and performed Kapalbhati correctly were included in the study. SBP and DBP were the cardiac parameters taken. Those parameters were taken before, immediately, after 1 minute, 2 minutes and 3 minutes of Pranayama. The data were entered in SPSS and Statistical analysis was done using version 23.

Results: As in usual exercises, SBP and DBP increases significantly immediately after Kapalbhati session when compared with the value before exercises. The basal (pre-Kapalbhati) mean SBP and DBP were $125.76 \pm 7.36$ and $82.92 \pm 5.75$ which increases up to $143.60 \pm 11.18$ and $90.33 \pm$ 7.90 respectively immediately after exercises and fall after 3 minutes of exercises value being $127.05 \pm 10.93$ and $81.38 \pm 5.38$ respectively.

Conclusion: There is significant rise between Pre-value and post-value (immediate) of all parameters and significant fall of all parameters if compared between post-value and after 3 minute.

Key words: Pranayama, yoga, Kapalbhati, Blood Pressure.

\section{INTRODUCTION}

Yoga is an ancient philosophical and religious tradition thought to have originated in India in 5000 BC. Now a days, modern medical physician also recommend yoga and yogic life style in stress related disorders such as obesity, hypertension, coronary artery diseases and diabetes mellitus, which are 
rooted in faulty life style and psychological stress. Yoga is the best lifestyle modification, which aims to attain the unity of mind, body and spirit through asanas (exercise), pranayamaa (breathing) and meditation [1, $16,17,20-22]$.

Regardless of its spiritual origins, yoga has become a popular route to physical and mental well- being [2, 3] and has been adapted for use in complementary and alternative medicine in North America and Europe [4, 16, 17, 20-22]. In Western societies, yoga is gaining increased popularity as a therapeutic method. About 14 million adult Americans (6.1\% of the population) reported that yoga had been recommended to them by a physician or therapist [5]. In the United Kingdom, yoga is even promoted by National Health Service as a safe and effective approach to improve health in both the general population and diseased patients [6]. Yoga has been shown to reduce important psychological cardiovascular disease risk factors such as stress [7, 8] and depression [9].

The study done by Malhotra et al suggested that there was significant drop of heart rate after practice of Chandra nadisuddhi pranayamaa in yogic and naive group but the drop was high in yogic group as compared to naive group [10]. Kapalbhati and its effect have not been studied well. Very few researches have been done to observe the effect of Kapalbhati. Recently, Nayak et al (2016) reported that cardiac parameters i.e. SBP, DBP and HR increases significantly during kapalbhati but when compared prekapalbhati data with post-kapalbhati data; increase was insignificant [11]. With this background, this study has been designed to see the acute effect and recovery time of kapalbhati pranayamaa among Naive i.e. new practitioners of yoga.

\section{MATERIAL AND METHODS}

The study was conducted by Department of Physiology, NGMCTH, Nepalgunj, Nepal during April 2016 to October 2016. Only healthy individuals are included in the study. Total sample size was 100 (50 males \& 50 females). A detailed demographic profile of the participants like height, weight, age was recorded and body mass index (BMI) was calculated. All the members of research group were actively involved in the collection of data and were cross checked by one another for any missed information. The aim and objective of the study were explained to each of them and verbal consent was taken. A baseline record of SBP (mmHg) and DBP (mmHg) were recorded before starting pranayamaa.

The participants were undergone to the supervised training of kapalbhati pranayamaa prior to the study. They were directed to sit in an easy and steady posture either in a lotus posture i.e. Padmasana or a comfortable sitting posture i.e. Sukhasana) with the head, neck and trunk erect and in a straight line and keep $t$ he body still during practice of pranayamaa in a calm and quiet room. Practice of kapalbhati was performed in following steps as followed by Nayak et al., [11] :

I. First sit on the padmasana and close your eyes and keep the spine straight.

II. Now take a deep breath through both nostrils until your lungs are full with air.

III. Now exhale through both nostrils forcefully, so your stomach will go 
deep inside. As you exhale you feel some pressure in your stomach.

IV. Repeat this process for next cycle.

They performed kapalbhati for 3 minutes (min. 100 strokes). With maintaining padmasana position, kapalbhati pranayamaa was performed and BP was noted immediately after the end of pranayamaa. The participants were instructed to take rest. SBP and DBP were measured by digital sphygmomanometer, Kroger, Automatic upper arm blood pressure monitor (Model No- BP3AQ1-1KRO) manufactured in China. The data were entered and analysed using SPSS statistical software (version 23).

\section{RESULTS}

Table 1: Demographic details of the subject

\begin{tabular}{|c|c|}
\hline Variables & Mean \pm SD \\
\hline Age (years) & $19.90 \pm 1.52$ \\
\hline Weight $(\mathrm{Kg})$ & $58.26 \pm 11.77$ \\
\hline Height $(\mathrm{cm})$ & $164.71 \pm 10.11$ \\
\hline BMI $\left(\mathrm{Kg} / \mathrm{m}^{2}\right)$ & $21.46 \pm 3.92$ \\
\hline Waist $(\mathrm{cm})$ & $79.89 \pm 11.11$ \\
\hline Skin Fold Thickness $(\mathrm{cm})$ & $2.60 \pm 0.77$ \\
\hline
\end{tabular}

Table 2: Comparison of mean of variables for Pre- and Post- Kapalbhati

\begin{tabular}{|c|c|c|}
\hline Variables & Pre & $\begin{array}{c}\text { Post } \\
\text { (Immediate) }\end{array}$ \\
\hline SBP $(\mathrm{mm}$ of $\mathrm{Hg})$ & $125.76 \pm 7.36$ & $143.60 \pm 11.18^{*}$ \\
\hline DBP (mm of Hg) & $82.92 \pm 5.75$ & $90.33 \pm 7.90^{*}$ \\
\hline
\end{tabular}

SBP: Systolic blood pressure; DBP: Diastolic blood pressure; *, Significant at $\mathrm{p}$ value $\leq 0.05$
Table 3: Comparision of mean of variables for post- and after 3 min- Kapalbhati

\begin{tabular}{||c|l|c|}
\hline Variables & $\begin{array}{c}\text { Post } \\
\text { (Immediate) }\end{array}$ & After 3 min \\
\hline SBP & $143.60 \pm 11.18$ & $127.05 \pm 10.93^{*}$ \\
\hline DBP & $90.33 \pm 7.90$ & $81.38 \pm 5.38^{*}$ \\
\hline \multicolumn{2}{|c|}{$\begin{array}{l}\text { SBP: Systolic blood pressure; DBP: Diastolic blood pressure; *, } \\
\text { Significant at p value } \leq 0.05\end{array}$} \\
\hline
\end{tabular}

Table 4 : Comparison of blood pressures Pre-, post- and after 1, 2, and 3 minutes after Kapalbhati

\begin{tabular}{|l|c|c|c|c|c|}
\hline Variable & Pre & Post & $\begin{array}{c}\text { After 1 } \\
\text { min }\end{array}$ & $\begin{array}{c}\text { After 2 } \\
\text { min }\end{array}$ & $\begin{array}{c}\text { After 3 } \\
\text { min }\end{array}$ \\
\hline SBP & 125.76 & 143.60 & 136.18 & 130.32 & 127.05 \\
& \pm & \pm & \pm & \pm & \pm \\
& 7.36 & 11.18 & 11.76 & 11.52 & 10.93 \\
\hline DBP & 82.92 & 90.33 & 86.90 & 84.43 & 81.38 \\
& \pm & \pm & \pm & \pm & \pm \\
& 5.75 & 7.90 & 6.72 & 4.91 & 5.38 \\
\hline
\end{tabular}

\section{DISCUSSION}

With increased awareness about health and increase interest in natural remedies, yogic techniques including pranayamaa are gaining importance and becoming increasingly acceptable among the scientific society [12, 16]. Patanjali, first proponent of yoga, described pranayama as the gradual unforced cessation of breathing [8, 17]. The ancient science of yoga makes use of voluntary regulation of the breathing to make respiration rhythmic and to calm the mind to reach the ultimate goal. This practice of pranayama is an art of controlling the breath $[9,15,16,17,21]$.

Kapalbhati is a pranayamaa which is made up of two words 'kapal' in Sanskrit means forehead and 'bhati' means shining. It is a fast, rhythmic breathing using abdominal muscles. Pranayamaa has been shown to alter autonomic activity $[11,12,16,18]$. Kapalbhati 
is a traditional internal purification practice or kriya that tones and cleanses the respiratory system by encouraging the release of toxins and waste matter, which can help to prevent illness and allergies. It acts as a tonic for the system, refreshing and rejuvenating the body and mind. Regular practice of kapalbhati strengthens the diaphragm and abdominal muscles $[13,17$, 18]. Chavhan 2013 explains importance of Kapalbhati by mentioning to affects even those diseases which are impossible to be cured by medicines like cancer, diabetes, asthma. Numerous patients have gained healthy and happy life by adopting it, in their daily life [15].

Several researches have shown the effect of various pranayama in cardiopulmonary functions $[\mathrm{A}-\mathrm{F}]$. Very few studies are focused on effect of Kapalbhati on human volunteers [11, 14, 15] among them Nayak et al. (2016) has studied the effect of Kapalbhati on cardiovascular parameters [11]. In the present study, there is significant rise between pre-value and post-value (immediately) of SBP and DBP whereas in the study done by Nayak et al (2016) there was rise in BP but the difference was insignificant [11].

Our study revealed that there is significant rise between Pre-value and post-value (immediate) of all parameters and significant fall of all parameters if compared between post-value and at the end of $3 \mathrm{~min}$. The results of the study indicated that unlike most yoga breathing exercises, Kapalbhati is initially energizing rather than calming; cleansing and heating, rather than cooling which indicates that there is sympathetic stimulation during Kapalbhati Pranayama.
In this study when we compared post-value (immediate) with at the end of $3 \mathrm{~min}$ of kapalbhati, there is significant decrease of all parameters towards the baseline. There is even fall of DBP after 3 minutes of finishing of Kapalbhati (table 4). This shows that the effect of Kapalbhati is not similar to that of effect of simple other type of exercise. This has some different effect. This may indicates that there is activation of parasympathetic activity or a decrease in a sympathetic activity which is shown by a decrease in blood pressure towards baseline or even below that. Further study regarding the mechanism of such output needs to be done, however some researcher have made some generalised speculation about the mechanism. As this Kapalbhati involves forceful exhalation and natural inhalation, it is a form of abdomino-respiratory-autonomi exercise.

At the time of practice of kapalbhati pranayamaa, respiratory, abdominal and gastrointestinal receptors get stimulated. Also, afferents, centers in brain stem and cortex and various efferent nerves (vagus) get stimulated. As a result, there is synchronous increase in autonomic nervous system, pineal gland, hypothalamus and other central nervous system discharge to all parts of the body [14] responsible for significant increase in blood pressure during kapalbhati pranayamaa in naive.

\section{CONCLUSION}

There is significant rise between pre-value and post-value (immediate) of all parameters and significant fall of all parameters if compared between immediate post-value and after 3 minutes value. Few studies has speculated and hypothesized some 
mechanism but further study regarding the mechanism of such output needs to be done.

\section{ACKNOWLEDGEMENT}

We would like to thank $1^{\text {st }}$ year MBBS students (2015 Batch) of Nepalgunj Medical College and Janaki Medical College, Nepal who participated in the study with interest and active participation.

\section{AUTHOR'S CONTRIBUTION}

SKJ- planning of research, training of kapalbhati pranayama, data collections and analysis; RKG- data collections and analysis; KUD- overall guidance and supervision on research work.

SOURCE OF SUPPORT: All the logistics were supplied by Department of Physiology, Nepalgunj Medical College.

CONFLICT OF INTEREST: None Declared.

\section{REFERENCES}

1. Iyengar BKS. Light on yoga. 7 th Edition. New Delhi: Harpercollins Publishers; 2002.

2. Feuerstein G. The yoga tradition. Prescott: Hohm Press; 1998.

3. Iyengar BKS. Light on yoga. New York: Schocken Books; 1966.

4. De Michaelis E. A history of modern yoga: Patanjali and western esotericism. London, UK: Continuum International Publishing Group; 2005.

5. Macy D. "Yoga in America" market study. Yoga J 2008. http://www.yogajournal.com/advertise/press releases $/ 10$

6. NHS. Your health, your choices. A guide to yoga.

http://www.nhs.uk/livewell/fitness/pages/y oga.aspx.

7. Chong CS, Tsunaka M, Tsang HW, Chan EP, Cheung WM. Effects of yoga on stress management in healthy adults: a systemic review. Altern Ther Health Med 2011; 17(1):32-8.

8. Michalsen A, Jeitler $M$, Brunnhuber $S$, et al. Iyengar yoga for distressed women: a 3-armed randomized controlled trial. Evid Based Complement Altern Med 2012; 408-727.

9. Cramer H, Lauche R, Langhorst J, Dobos G. Yoga for depression: a systematic review and meta-analysis. Depress Anxiety 2013; 30: 1068-83.

10. Malhotra V, Upadhyay-Dhungel K, Ganga J. Does the effect of pranayama differ in yoga practitioner and Naïve? J Clin and Diag Res 2010; 4: 3503-06.

11. Nayak R, Prakash S, Yadav RK, UpadhyayDhungel K. Kapalbhati changes cardiovascular parameters. Janaki Med Coll J Med Sci 2015; 3(2): 43-49.

12. Subbalakshmi KN, Saxena KS, Souza JAU. Immediate effect of Nadishodhan pranayama on some selected parameters of cardiovasular, pulmonary and higher functions of brain. Thai J Physiological Sci 2005; 18(2): 10-16, 2005.

13. Yogananda PS. God Talks with Arjuna. The Bhagavad Gita, Royal Science of GodRealization. The immortal dialogue between soul and spirit. A new translation and commentary, chapter IV verse 29; 2002. pp 496-507.

14. https://www.yogaoutlet.com/guides/how-topractice-kapalabhati-pranayama-in-yoga.

15. Chavhan DB. The Effect of Anulom-Vilom and Kapalbhati Pranayamaa on Positive Attitude in School Going Children. Edubeam Multidisciplinary- Online Res J 2013; 1: 1-8.

16. Prakash S, Upadhyay Dhungel K. Chandra Anuloma Viloma Pranayama modifies Cardiorespiratory Functions. Janaki Med Coll J Med Sci 2015; 3 (1):45-51.

17. Upadhyay Dhungel K, Malhotra V, Sarkar D, Prajapati R. Effect of alternate nostril breathing exercise on cardiorespiratory functions. Nepal Med Coll J 2008; 10 (1):25-7.

18. Malhotra V, Patil R, Malhotra M, Upadhayay et al. Chandra Anuloma Viloma Pranayama modifies autonomic activity of heart. BAPT 2008; 2(1):27-28.

19. Varun Malhotra, Jai Ganaga, Saumya, Navin R, Srinivas Ragavan, Upadhyay Dhungel K, Pranayama and Heart. National J Basic Med Sci 2010; 1(1): 11-14.

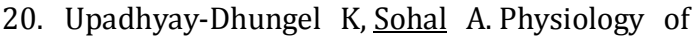
nostril breathing exercises and its probable 
relation with nostril and cerebral dominance: A theoretical research on literature. JMCJMS, 2013; 1(1):38-47.

21. Kekan D, Kashalikar S. Effect of Kapalbhati Pranayamaa on waist and hip circumference. J Evol Med Dental Sci 2013; 2 (11): 1695-1699.

22. Dinesh T, Gaur GS, Sharma VK et al.. Effect of 6 Weeks of Kapalabhati Pranayama Training on Peak Expiratory Flow Rate in Young, Healthy, Volunteers. Sch Acad J Biosci 2013; 1(4):112114.

\section{Correspondence to: Santosh Kumar Jha \\ Lecturer \\ Department of Physiology \\ Nepalgunj Medical College Teaching \\ Hospital, Nepalgunj, Nepal \\ Email: blueskysantosh@gmail.com}

